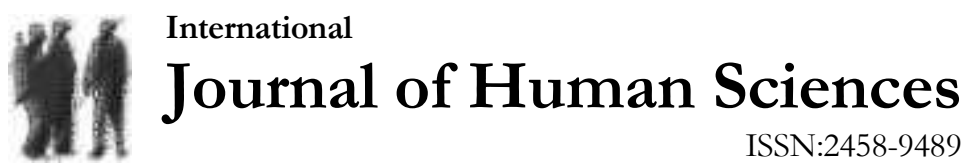

Volume 17 Issue 1 Year: 2020

\section{The actors of teacher supervision ${ }^{1}$}

\author{
Burcu Altun ${ }^{2}$ \\ Pinar Yengin Sarpkaya ${ }^{3}$
}

\begin{abstract}
Educational supervision is a process aiming to enhance teaching by developing teacher. The position and the quality of supervisor are of great importance for effective supervision experiences. The purpose of this research is to determine the actors carrying effective teacher supervision. So, school administrators and teachers working in general high schools and supervisors working in provincial directorate of national education in Efeler district of Aydin/Turkey are asked for their opinions. Results show that participants suggest different supervisory actors in different dimensions of teacher supervision. Generally, the school principal, vice-principal, head of the department and student preferences have come to the fore. Teachers, administrators and supervisors suggest different supervisory actors.
\end{abstract}

Keywords: Teacher supervision; supervisory actors; supervision; inspection.

\section{Introduction}

Today, the quality of education is the key factor in the welfare of countries. In order to provide qualified education services, the focus of educational policies should be sustainable development. In order to initiate and sustain the targeted developments in education, it is necessary to determine the current situation correctly, to identify strong and weak points, to analyze the effectiveness of the methods and techniques applied and to guide the education and training process by experts. All these are possible by the healthy operation and renovation of educational supervision as a subsystem of education system.

\section{Literature Review}

Supervision in education is a professional guidance and support which is provided when and where it is necessary, and applied to all levels of education (Taymaz, 2011, 4). It is the process which is composed of analysis, evaluation, correction and development elements (Başar, 1998, 4), consists of administrative, contextual and educational actions (Wiles and Bondi, 2000, 11-13) and is the center of developing teaching (Sullivan ve Glanz, 2009, 4; Kalule and Bouchamma, 2007, 90).

\footnotetext{
${ }^{1}$ This article is a part of master thesis named as "Critical Approach to Teacher Supervision: How Teacher Supervision Should Be?

2 Research Assistant, Adnan Menderes University, Faculty of Education, Department of Educational Sciences, burcualtun88@gmail.com; (ID) Orcid ID: 0000-0002-8564-829X

3 Assoc. Prof. Dr., Adnan Menderes University, Faculty of Education, Department of Educational Sciences, pinar@sarpkaya.net; (D) Orcid ID: 0000-0001-8379-7083
} 
In theory, many details can be discussed about the aim, function and necessity of teacher supervision, on the other hand, in practice; there is a negative perception about supervision. Because it is seen as a compulsory process which is applied by educational authorities and initiated by supervisor or school principal. This causes two main problems from the very beginning. First, supervision is perceived as equivalent to evaluation and it is inevitable for teachers to become nervous and anxious because of being tested and evaluated. Second, it is seen to be arisen from supervisor's needs rather than teachers' (Acheson and Gall, 2003, 6). Of course supervision includes the evaluation of teacher's professional skills and effectiveness of school's program by supervisor (Sergiovenni and Starratt, 1979, 268) but attributing only these functions to supervision hinders the effective and efficient use of it. Contemporary supervisory perspective focuses on learning experiences rather than testing teachers as it is in traditional perspective (Erdem and Sarpkaya, 2011).

The purpose of teacher supervision should be to develop teachers' pedagogical skills to enhance pupils' success (Marzano, Frontier and Livingston, 2011, 2). Who will perform teacher supervision is an important problem in many countries' education system. According to Ministry of National Education of Turkey, the key stakeholders of supervision are learners, teachers, parents, principals, educational staff and society (MoNE, 2011), on the other hand, legal supervision authority belongs to school principal (MoNE, 2003) and supervisors (MoNE, 2014). By current legal regulations, classroom supervision duty is left to school principals (MoNE, 2016a; MoNE, 2016b).

The actors that will perform supervisions are critical for the efficiency and effectiveness (Bates and Burbank, 2019). Although there are different international tendencies, the general emphasis is shaped around legal regulations. Enns (1965) questions effect of supervisory visits of supervisors on developing teaching and points out that most of the time and resources may be wasted. He addresses the additional administrative responsibilities of school principals and concludes that it is also not healthy to ascribe all the supervisory roles to school principals. Supervisorship is a leadership and guidance process (Glickman, Gordon, Ross-Gordon, 2009, 9) and there may be different subjects to perform it. School principals, colleagues, students, supervisors and parents may take a role in teachers' supervision. Additionally, supporting selfsupervision of teachers is another supervisory approach.

\section{School Principal as a Supervisory Actor}

Unlike other organizations, production in school organizations is about human. The responsibility of controlling and supervising the quality of this production belongs primarily to school principal. Schools have recognized the importance of approaching supervision in different ways to satisfy teachers' professional developmental needs (Wolform, 2009, 5). In developed countries' education systems, most of the supervisory roles of supervisors had been transferred to school principals (Bursalıoglu, 2012, 34). The basic responsibility of school principal is to guarantee qualified teaching and learning in classrooms (Sindhvad, 2009). In its simplest form, today, a school principal has to influence the thinking of teachers (Henson, 2010, 70).

Today, the importance of principal's supervisory roles in teacher development has been increasing day by day. It is due to new leadership roles, changes in supervisory approaches, guidance and development perspective, relationship between supervisory actions and school development, necessity of developing educational staff. Those facts which are "getting better supervisory results from the inner structure of the school, inadequate number of professional supervisors, teachers' preferences, negative feelings for supervisors' supervisory actions and some other problems of supervision system" could be stated that they bring school principal's supervision role into the front (Yllmaz, 2009, 25).

According to the results of Aslanargun and Göksoy's (2013, 105-106) research, most of the teachers prefer school principal's supervision because of negative aspects of supervisions made by supervisors. Results reveal that principals, as being member of school organization, have a chance 
to observe teachers for a long period of time and may evaluate teachers from different views. It is necessary not to forget the main purpose of teacher supervision is to develop effectiveness of school and teaching. Effective schools need qualified and supportive leader principals and to do so, by focusing on teaching, school principals should be visible in classrooms (Grizzard, 2007).

\section{Peer as a Supervisory Actor}

The main purpose of peer supervision is to provide education stakeholders with opportunities to share ideas, learn from each other, and support each other for achievement of learning outcomes (Sullivan and Glanz, 2009). Any teacher's departmental peer, departmental head or colleague from different field may provide feedback by observing his lecture or analyzing his instructional works. Some teachers prefer to be supervised by peers from the same department rather than supervisor or school principal (Altun and Yengin Sarpkaya, 2014). According to results of an action research supporting the effectiveness of peer supervision, departments in schools may become learning teams by peer support (Bayrak and Yengin Sarpkaya, 2016). Peer supervision aims to develop instruction and increases sharing about instruction (Sullivan and Glanz, 2009, 145). Today, supervision faces with an era of crisis and practices including collaboration, decision making, and reflective listening are essential for educational settings (Sullivan and Glanz, 2000). These practices can be carried out by peer supervision.

\section{Student as a Supervisory Actor}

It is possible to make an inference about teacher's instructional skills by using data gathered from students. Student surveys, evaluation forms and some other assessment tools provide information about teacher's teaching skills from students' perspective (Marzano et all, 2011, 65). Today, in some universities and institutions, instructors are evaluated by students and this practice may be transferred to other education levels.

Developments point out the necessity of being involved in inquiry based school climate for students. Student involvement is possible by giving them chance to involve in decision making process in possible dimensions of teaching - learning cycle. Student participation is a prerequisite for success (Henson, 2007, 16). It may be a significant initiative to bring supervision into force that students should have a share in teacher supervision. Today in educational settings students already evaluates teachers implicitly, so systematic evaluative practices may become effective supervisory tools.

\section{Supervisor as a Professional Actor}

Supervisors are the ones who occupationally evaluate and guide teachers. The field expert supervisors are crucial to make educational supervision practices scientific and systematic. As the main purpose of teachers is to develop students' behaviors, attitudes and success, similarly the main purpose of supervisors is to develop teachers' behaviors, attitudes and success (Glickman et all, 2009, 79). Todays' educational supervisors come face to face with complex, social, political, technological and ethical issues, so they have to develop educative and meaningful programs ever before (Sullivan and Glanz, 2009, 47), since they are professionally responsible from supervisory process.

\section{Teacher Herself/Himself as a Supervisory Actor: Self-Supervision}

An employee's self-supervision in an organization is the evaluation of his/her own behaviors with respect to predetermined organizational criteria (Başaran, 1989, 319). There are many ways for a teacher to improve self-supervisory skills.

Visiting another senior teacher's lesson and making comparisons about teaching practices, recording its own lecture and analyzing it, applying survey or interview forms to students and parents, conferencing with supervisors, colleagues, students and parents about effective teaching or its own teaching practices, keeping diary with critical manner for developing instructional practices, reviewing students' exam scores and works, creating portfolio about teaching process are some of the ways of self-supervision (Glickman et all., 2009, 221). 
Encouraging self-supervision and supporting it will help teachers to check themselves for instructional development. The success of this process is related to the ability of teacher to work productively and constructively on its own hook (Knoll, 1987, 167). Also, the guidance of principal or supervisor is necessary in this process (Başaran, 1989, 319).

\section{Parents as Supervisory Actors}

Although parents do not directly provide data about in-class activities, they are the stakeholders who may observe teachers from various perspectives. They may provide indirect information about teacher's instructional skills, strengths and weaknesses. Despite all the efforts and dedication of the supervisor, it is not possible to recognize every detail at once (Knoll, 1987), so, to get information from different stakeholders will help to see a wider picture. For instance, some principals think that parents and students are effective supervisory actors since they are conscious, good observer and strict followers of teaching process (Altun and Sarpkaya, 2014). Parents are essential stakeholders of teacher supervision (Aydin, 2013, 187).

One of the prerequisites of sustainable success in education is to follow and evaluate the system by supervision and to develop it accordingly. During the research period, teacher supervision was the duty of ministerial supervisors, local supervisors and school principals. In that period, MoNE was looking for supervisory regulations. This idea directs us to the importance of research studies about supervision. Not only system requirements but also inadequacies in theory and practice address the emergency of thinking, searching and working on supervision. So, in this research it is aimed to get the opinions of supervisors, school administrators and teachers as supervisory actors about teacher supervision. The aim of educational supervision is to create effective schools (MoNE, 2011) and effective schools are the ones in which effective learnings are experienced (Balc1, 2007). Since the effectiveness of the schools is the product of stakeholders' collaborative efforts (Brookover, Ericson and McEvoy, 1995), their opinions are crucial for the supervisory success.

The purpose of this research is to determine the actors who can carry out effective teacher supervision process according to supervisors', school administrators' and teachers' opinions. The main research questions are:

1. What are the opinions of supervisors, school administrators and teachers about "who should be the actors of teacher supervision?"

2. How participants' opinions differ in terms of their professions as supervisors, school administrators and teachers?

\section{Methodology}

\subsection{Research model}

This research aiming to evaluate teacher supervision in practice by participants' opinions is a survey research. Survey researches aim to describe a case with its current characteristics (Rossi, Wright and Anderson, 2013; Creswell, 2012, 376) by getting individuals' opinions about that case or phenomenon (Lodico, Spaulding and Voegtle, 2006, 157; Scott and Morrison, 2007, 232).

\subsection{Population and Sample}

The target population of the research is school administrators (principals and vice principals) and teachers working in general public high schools in Efeler province in Aydin, Turkey, and supervisors working in Aydin Provincial Directorate for National Education. According to Regulation on Secondary Education Institutions of Ministry of National Education, science, social science and anatolian high school (MoNE, 2013) are included in population as they are all general high schools, on the other hand fine arts high school is not included due to differences in curriculum by expert opinion. Since the target population is accessible, it is aimed to reach to all of the target population as 523 teachers and 37 school administrators working in 9 general public high schools and 33 supervisors working in provincial directorate for national education. At the end of the data collection process, 258 participants' data were used. 
Altun, B. \& Yengin Sarpkaya, P. (2020). The actors of teacher supervision. Journal of Human Sciences, 17(1), $284-303$. doi:10.14687/jhs.v17i1.5880

\subsection{Data Collection Instrument}

The instrument was designed as a questionnaire which is frequently used in qualitative research studies in social sciences (Erdogan, 2012, 216), suitable for survey researches (Muijs, 2004, 36) and provides data from primary sources (İslamoğlu and Alnıçık, 2013, 129; Aziz, 2013, 83).

The data collection tool used in the research consists of two parts. Part-I is "Opinions about Teacher Supervision" and Part II is "Personal Information". In the Part-I, there are 52 items reflecting the situations to be evaluated under teacher supervision. The participants are asked by whom these 52 items should be supervised. To take participants' opinions, "School Vice Principal", "School Principal", "MoNE Provincial Supervisor (Local Supervisor)", "MoNE Ministry Supervisor (Central Supervisor)", "Head of Department", "Student" and "Other" options are presented next to each item. By "Other" option, participants were given a chance to suggest different supervisory actors than the existing options. Participants are expected to select at least two options for each item. In Part-II, there are eight items about their demographic variables.

The questionnaire was developed by the researchers based on the Teacher Evaluation Form in the Teacher Supervision Guide of the Ministry of National Education (2011). In addition to the dimensions and criteria in the form, a document supervision dimension and related items were added and item pool was created. Opinions were taken for the items in the pool from administrators, teachers and 4 academician of Aydin Adnan Menderes University Faculty of Education. After the questionnaire was put into final form, the pilot study was held with 40 administrators and teachers. The data gathered from the pilot study were used to change some items and directives. In brief, the main steps of questionnaire development as constructing items, asking for expert opinion, conducting a pilot study, analyzing the data and revising the items (Büyüköztürk, 2005, 3) were followed. Teachers, school administrators and 4 academicians were asked for their opinions during revision process. Finally, questionnaire consisting of 52 items in 7 dimensions was constructed. The dimensions and related items are as follows:

Document Supervision includes 9 items about documents of teacher's plans, measurement and assessment, instructional works and individual studies. (Items 1, 2, 3, 4, 5, 6, 7, 8 and 9).

Planning the Lesson includes 12 items about how teacher plans its lessons effectively. (Items 10, $11,12,13,14,15,16,17,18$ and 19).

Learning/Teaching Environment, Materials and Technologies includes 7 items ranging from cleanliness and the organization of the physical environment to selection of materials and other arrangements. (Items 20, 21, 22, 23, 24, 25 and 26).

Valuing and Guiding Student includes 8 items about communication of teacher with students, duties of teacher to lead and guide students. (Items 27, 28, 29, 30, 31, 32, 33 and 34).

Special Field Program / Content Knowledge includes 4 items about teacher's knowledge and skills related to its special field. (Items 35, 36, 37 and 38).

Teaching Process includes 9 items about basic characteristics teacher should take into consideration during teaching. (Items 39, 40, 41, 42, 43, 44, 45, 46 and 47).

Individual Characteristics includes 5 items about teacher's desired characteristics to be a good teacher. (Items 48, 49, 50, 51 and 52).

\subsection{Validity of the data collection instrument}

For the content validity of questionnaire, 4 field experts were asked for their opinions and as a result $7^{\text {th }}$ dimension named as Document Supervision and related items was added to the item pool in addition to the 6 dimensions of MoNE's Teacher Evaluation Form. As a result, the questionnaire was designed to take participants opinions comprehensively with 7 dimensions and 52 items.

For the face validity which is basic one (Neuman, 2007, 118), an introduction part was added to questionnaire, the whole instrument was split into meaningful parts and sequential item lines were colored in different tones to make readers read and answer easily. 
Altun, B. \& Yengin Sarpkaya, P. (2020). The actors of teacher supervision. Journal of Human Sciences, 17(1), 284-303. doi:10.14687/jhs.v17i1.5880

\subsection{Data collection and analysis}

The questionnaire was presented to the participants in printed form and the participants were accompanied and guided through the process of filling the questionnaire and the gains to be obtained by completing the questionnaire were emphasized. The application process is composed of pilot study with administrators and teachers and the main study with administrators, teachers and supervisors. For the data analysis, descriptive statistics were utilized. Multiple responses set was created and used, frequencies of those multiple responses were calculated (Can, 2013). The distribution of answers according to professions of participants was analyzed. The SPSS 21.0 program was used for data analysis. Moreover, the findings of this research are limited to the perception of participants about supervision such as control, developmental process, cooperation, evaluation and so on.

\section{Findings}

The analysis of distribution of 258 participants based on their profession reveals that $79,5 \%$ of them are teachers, $7,1 \%$ of them are school administrators and $12,4 \%$ of them are supervisors. 3 participants did not share information about their profession. Findings of the research are represented and classified by dimensions of questionnaire. The percentages in the table have been calculated not based on the participants, but on their responses.

\subsection{Findings of First Problem of Research}

Findings about "Who should be the actors of teacher supervision according to opinions of supervisors, school administrators and teachers' are represented in Table 1. In Table, only the percentages of most frequently preferred 3 options are given.

\begin{tabular}{|c|c|c|c|c|c|c|c|c|c|c|}
\hline & & & Supe & visory & Actors a & Ind Prefe & rability & Perce & ges & \\
\hline 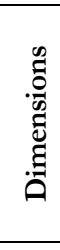 & 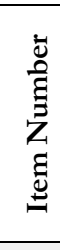 & Topic of supervision & 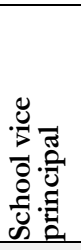 & 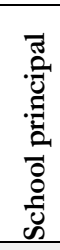 & 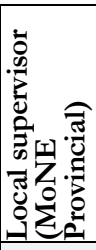 & 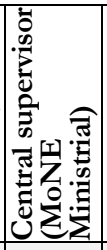 & 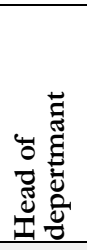 & 苞 & $\stackrel{\grave{E}}{\stackrel{ \pm}{0}}$ & 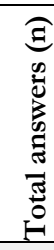 \\
\hline \multirow{9}{*}{ 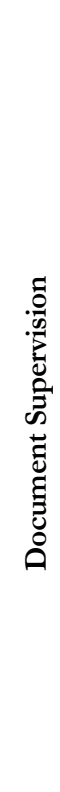 } & 1 & Minutes of Department Meeting & 17,2 & 43,9 & & & 19,3 & & & 367 \\
\hline & 2 & $\begin{array}{l}\text { Annual Plans with Chapters (annual aims appropriate for } \\
\text { each student, selection and timing of chapters, convenience } \\
\text { of methods...) }\end{array}$ & 16,6 & 47,7 & & & 14,8 & & & 344 \\
\hline & 3 & $\begin{array}{l}\text { Exams and other measurement and assessment practices } \\
\text { (preparation, distribution of topics, preparation of answer } \\
\text { key, announcement of exam dates, duration...) }\end{array}$ & 22,0 & 40,9 & & & 20,8 & & & 337 \\
\hline & 4 & $\begin{array}{l}\text { Evaluation Results (appropriate measurement and } \\
\text { assessment, announcement of results, recording the grades } \\
\text { to school's database...) }\end{array}$ & 27,6 & 39,2 & & & 17,2 & & & 337 \\
\hline & 5 & $\begin{array}{l}\text { Homeworks (Planning, coherence with the aim, follow up, } \\
\text { evaluation...) }\end{array}$ & 28,9 & 32,1 & & & 21,3 & & & 305 \\
\hline & 6 & $\begin{array}{l}\text { Social Activities (Works of students clubs and community } \\
\text { services about scientific, social, cultural, artistic and sports } \\
\text { areas) }\end{array}$ & 29,4 & 43,1 & 13,8 & & & & & 320 \\
\hline & 7 & $\begin{array}{l}\text { Guidance and Counselling Practices (Educational, } \\
\text { occupational, individual and group activities and parent } \\
\text { involvement) }\end{array}$ & 27,0 & 42,2 & 15,5 & & & & & 341 \\
\hline & 8 & $\begin{array}{l}\text { Duties and Responsibilities (Teaching, ceremonies, } \\
\text { appearance, helping administrators...) }\end{array}$ & 32,1 & 51,4 & 12,0 & & & & & 333 \\
\hline & 9 & $\begin{array}{l}\text { Personal Works (In service education, meetings, seminars, } \\
\text { graduate programs, national and international projects and } \\
\text { scientific publications...) }\end{array}$ & 20,8 & 46,9 & 23,6 & & & & & 288 \\
\hline
\end{tabular}


Altun, B. \& Yengin Sarpkaya, P. (2020). The actors of teacher supervision. Journal of Human Sciences, 17(1), 284-303. doi:10.14687/jhs.v17i1.5880

\begin{tabular}{|c|c|c|c|c|c|c|c|c|}
\hline \multirow{10}{*}{ 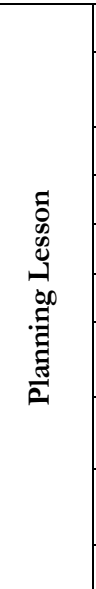 } & 10 & Planning the lesson with effective time management & 14,9 & 43,7 & & 16,6 & & 295 \\
\hline & 11 & $\begin{array}{l}\text { Reflecting the aims and principles of national education to } \\
\text { plans and practices. }\end{array}$ & 16,0 & 49,1 & 18,9 & & & 344 \\
\hline & 12 & Planning student centered lessons & 17,7 & 39,9 & 16,0 & & & 298 \\
\hline & 13 & Considering individual differences in lesson plans & 17,7 & 39,9 & 16,0 & & & 288 \\
\hline & 14 & Defining the aims and objectives in lesson plans & 18,3 & 42,3 & 15,3 & & & 300 \\
\hline & 15 & Specifying the purposeful activities in lesson plans & & 40,8 & 16,8 & 18,5 & & 292 \\
\hline & 16 & $\begin{array}{l}\text { Specifying the purposeful methods and techniques in lesson } \\
\text { plans }\end{array}$ & & 39,8 & 15,5 & 20,8 & & 284 \\
\hline & 17 & $\begin{array}{l}\text { Specifying the resources and materials will be used in lesson } \\
\text { plans }\end{array}$ & 16,4 & 38,7 & & 24,1 & & 274 \\
\hline & 18 & $\begin{array}{l}\text { Indicate how to use information and communication } \\
\text { technologies in lesson plans }\end{array}$ & 16,2 & 37,5 & & 21,7 & & 277 \\
\hline & 19 & Specifying the homeworks in lesson plans & 19,1 & 35,2 & & 24,7 & & 267 \\
\hline \multirow{7}{*}{ 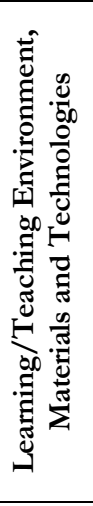 } & 20 & $\begin{array}{l}\text { Taking necessary precautions for hygiene and ventilation of } \\
\text { learning environment }\end{array}$ & 34,3 & 43,0 & 7,8 & & & 309 \\
\hline & 21 & $\begin{array}{l}\text { Organizing learning environment in accordance with type of } \\
\text { activities }\end{array}$ & 29,0 & 44,8 & 10,1 & & & 286 \\
\hline & 22 & $\begin{array}{l}\text { Arranging the physical conditions (heat, light, noise etc.) of } \\
\text { learning environment to ease the learning }\end{array}$ & 33,0 & 44,3 & 9,2 & & & 327 \\
\hline & 23 & $\begin{array}{l}\text { Considering the characteristics of students while selecting } \\
\text { materials, resources and activities to ease learning }\end{array}$ & 20,1 & 38,2 & 12,2 & & & 304 \\
\hline & 24 & Maintaining and keeping ready the lesson equipments & 31,4 & 39,4 & & 10,9 & & 322 \\
\hline & 25 & $\begin{array}{l}\text { Reflecting the developments of information and } \\
\text { communication technologies to lessons }\end{array}$ & 20,8 & 39,6 & & 14,0 & & 308 \\
\hline & 26 & $\begin{array}{l}\text { Being role model effective use of technological resources } \\
\text { and teaching them }\end{array}$ & 19,0 & 40,5 & 14,5 & & & 289 \\
\hline \multirow{8}{*}{ 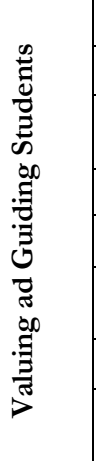 } & 27 & Calling students by their names & 21,6 & 35,7 & & & 13,7 & 227 \\
\hline & 28 & Listening students effectively & 21,9 & 37,1 & & & 13,1 & 251 \\
\hline & 29 & $\begin{array}{l}\text { Reacting positively when students give different responses to } \\
\text { questions }\end{array}$ & 19,1 & 37,0 & & & 14,0 & 257 \\
\hline & 30 & Providing opportunities for students to express themselves & 20,8 & 36,2 & & & 14,0 & 265 \\
\hline & 31 & Including respect elements in speeches and behaviors & 20,4 & 39,8 & & & 14,1 & 269 \\
\hline & 32 & $\begin{array}{l}\text { Directing students to use their in-class and extra-curricular } \\
\text { time effectively }\end{array}$ & 20,7 & 34,1 & & 13,8 & & 261 \\
\hline & 33 & Making all students to work purposefully and planned & 20,8 & 37,5 & & 13,1 & & 259 \\
\hline & 34 & $\begin{array}{l}\text { Using the right strategies to make students obey the school } \\
\text { rules }\end{array}$ & 22,8 & 41,5 & 10,3 & & & 272 \\
\hline \multirow{4}{*}{ 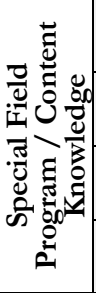 } & 35 & $\begin{array}{l}\text { Reflecting the aims, principals and approaches of special } \\
\text { field program to plans and practices }\end{array}$ & 19,6 & 41,5 & 14,3 & & & 265 \\
\hline & 36 & $\begin{array}{l}\text { Providing students with necessary learning ways in special } \\
\text { field }\end{array}$ & 18,6 & 40,3 & 15,5 & & & 258 \\
\hline & 37 & $\begin{array}{l}\text { Transferring theories, principles and concepts related to } \\
\text { special field in a way that students understand }\end{array}$ & 16,9 & 39,2 & 14,2 & & & 260 \\
\hline & 38 & $\begin{array}{l}\text { Reflecting developments related to special field to lessons } \\
\text { (philosophy, theory, approach...) }\end{array}$ & 19,3 & 38,5 & 13,3 & & & 270 \\
\hline \multirow{8}{*}{ 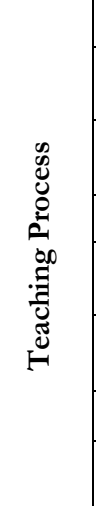 } & 39 & Motivating students to learn by attracting their attention & 16,5 & 38,4 & & 12,7 & & 284 \\
\hline & 40 & $\begin{array}{l}\text { Examining the readiness of students in terms of knowledge, } \\
\text { skills and/or values to understand the topic }\end{array}$ & 19,7 & 38,0 & & 14,7 & & 279 \\
\hline & 41 & $\begin{array}{l}\text { Putting the content in gradual order according to } \\
\text { characteristics of topics }\end{array}$ & 18,5 & 36,2 & & 20,7 & & 271 \\
\hline & 42 & Relating the topic of the lesson with the previous topics & 15,8 & 37,0 & & 19,4 & & 273 \\
\hline & 43 & $\begin{array}{l}\text { Encouraging the learning efforts of students at different } \\
\text { levels }\end{array}$ & 16,4 & 36,4 & & 17,5 & & 275 \\
\hline & 44 & $\begin{array}{l}\text { Using the effective inquiry techniques supporting higher } \\
\text { order thinking skills }\end{array}$ & 17,7 & 35,7 & & 17,3 & & 266 \\
\hline & 45 & Giving immediate feedback and correction to students & 17,9 & 33,2 & & 17,9 & & 268 \\
\hline & 46 & $\begin{array}{l}\text { Using voice tone, gestures and mimics effectively in teaching } \\
\text { process }\end{array}$ & 15,6 & 37,0 & & 16,3 & & 257 \\
\hline
\end{tabular}


Altun, B. \& Yengin Sarpkaya, P. (2020). The actors of teacher supervision. Journal of Human Sciences, 17(1), $284-303$. doi:10.14687/jhs.v17i1.5880

\begin{tabular}{|c|c|c|c|c|c|c|c|}
\hline & 47 & $\begin{array}{l}\text { Creating opportunities for students to relate what they have } \\
\text { learned with their lives }\end{array}$ & 17,1 & 36,4 & 15,5 & & 258 \\
\hline \multirow{5}{*}{ 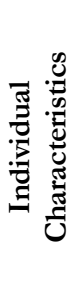 } & 48 & $\begin{array}{l}\text { Acting in accordance with social and professional ethical } \\
\text { values in class activities }\end{array}$ & 20,1 & 38,4 & 13,1 & & 289 \\
\hline & 49 & Taking care of personal care & 24,3 & 42,1 & & 11,4 & 280 \\
\hline & 50 & Using Turkish language grammatically and understandably & 18,0 & 40,8 & 13,5 & & 289 \\
\hline & 51 & Being a technology literate & 18,4 & 41,8 & 11,0 & & 282 \\
\hline & 52 & Using time effectively in teaching-learning process & 18,4 & 41,8 & 11,7 & & 299 \\
\hline
\end{tabular}

Participants generally prefer the supervision of the school principal and the vice principal in document supervision dimension. The head of the department is preferred to a considerable extent. The MoNE provincial supervisor is chosen in the third place only for the supervision of social activities, guidance activities, duties and responsibilities and personal activities. MoNE ministry supervisors and students are generally not preferred. The preferences are focused around the school principal, vice principal, the head of the department and the MoNE provincial supervisor. Among these preferences, the school principal has the highest rate.

Participants generally prefer the supervision of the school principal, vice principal, head of the department and MoNE provincial supervisor in planning lesson dimension. The most preferred supervisory actor after the school principal is the head of the department. In the supervision of items 11,12,13 and 14, the MoNE provincial supervisor is preferred most after the school principal and vice principal. Participants generally prefer the supervision of the school principal and the vice principal in teaching / learning environment materials and technologies dimension. These preferences are followed by the MoNE provincial supervisor.

Participants generally prefer the supervision of the school principal and the vice principal in the dimension of valuing and guiding students. The student preference is the third one. Findings show that the student can also take an active role in teacher supervision process in this dimension. The choices of the participants are mainly focused on school principal and vice principal in terms of special field program / content knowledge dimension as supervisory actors, followed by the MoNE provincial supervisor.

The participants preferred the supervision of the school principal, vice principal and head of the department in terms of the teaching process dimension. In this dimension, a supervisory actor other than the school principal, vice principal and head of the department is not preferred in the first three. When the opinions of the participants regarding the individual characteristics dimension are examined, it is seen that school principal and assistant school principal are generally preferred. These preferences are followed by the head of department and student.

In summary, the participants prefer the school principal among the actors who can take role in teacher supervision. The vice principal is also highly preferred. Especially in branch related activities, the head of the department is one of the most preferred actors. The student option has also been proposed to a considerable extent, especially in the dimension of valuing and guiding student. The vice principal, the head of the department and the student are among the actors most recommended by the participants, although they do not have legal supervision duties. Despite the legal compulsory supervision duty of the MoNE provincial supervisor, it has been rarely preferred in some dimensions. It is seen that the Ministry supervisor cannot be among the top three preferences in any dimensions. In addition, in the other category, where percentage is not presented in the table, options such as self-supervision, peer supervision, parents, guidance counselor were suggested.

\subsection{Findings of Second Problem of Research}

Findings about the distribution of the opinions based on the profession related to "who should be the actors of teacher supervision?" are represented in Table 2 and only the percentages of most frequently preferred 3 options are given. 
Altun, B. \& Yengin Sarpkaya, P. (2020). The actors of teacher supervision. Journal of Human Sciences, 17(1), 284-303. doi:10.14687/jhs.v17i1.5880

When the opinions of the participants as teachers, administrators and supervisors examined comparatively based on their profession, it is seen that different profession groups have different expectations about the actors who will perform the teacher supervision. The findings are represented in order of professions. First teachers' opinions, then administrators' and finally supervisors' opinions are represented respectively.

\begin{tabular}{|c|c|c|c|c|c|c|c|c|c|c|c|}
\hline \multicolumn{12}{|c|}{$\begin{array}{l}\text { Table 2. Distribution of Participants' Opinions About Who Should Supervise Teachers? Based on Their } \\
\text { Professions }\end{array}$} \\
\hline \multirow[b]{2}{*}{ 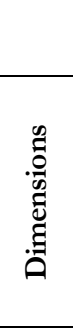 } & \multirow[b]{2}{*}{ 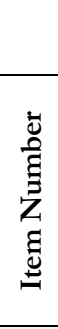 } & \multirow[b]{2}{*}{ Topic of supervision } & & \multicolumn{7}{|c|}{$\begin{array}{l}\text { Supervisory Actors and Preferability } \\
\text { Percentages }\end{array}$} & \multirow[b]{2}{*}{ 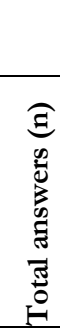 } \\
\hline & & & & 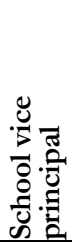 & 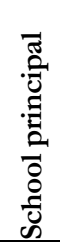 & 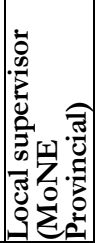 & 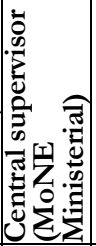 & 峞 & 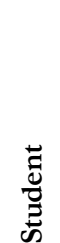 & $\frac{\ddot{\Xi}}{\tilde{\Xi}}$ & \\
\hline \multirow{27}{*}{ 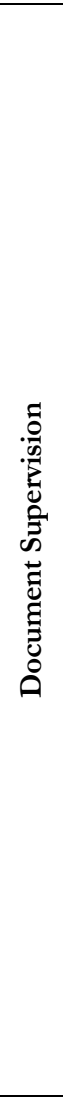 } & \multirow{3}{*}{1} & \multirow{3}{*}{ Minutes of Department Meeting } & Teachers & 20,7 & 44,7 & & & 20,7 & & & \multirow{3}{*}{364} \\
\hline & & & Administrators & 14,3 & 53,6 & 25,0 & & & & & \\
\hline & & & Supervisors & & 37,1 & 37,1 & & 22,9 & & & \\
\hline & \multirow{3}{*}{2} & \multirow{3}{*}{$\begin{array}{l}\text { Annual Plans with Chapters (annual aims } \\
\text { appropriate for each student, selection and } \\
\text { timing of chapters, convenience of } \\
\text { methods...) }\end{array}$} & Teachers & 19,8 & 46,7 & & & 18,3 & & & \multirow{3}{*}{341} \\
\hline & & & Administrators & 13,8 & 55,2 & 24,1 & & & & & \\
\hline & & & Supervisors & & 49,1 & 43,6 & & 5,5 & & & \\
\hline & \multirow{3}{*}{3} & \multirow{3}{*}{$\begin{array}{l}\text { Exams and other measurement and } \\
\text { assessment practices (preparation, } \\
\text { distribution of topics, preparation of answer } \\
\text { key, announcement of exam dates, } \\
\text { duration. . }\end{array}$} & Teachers & 24,4 & 39,2 & & & 26,4 & & & \multirow{3}{*}{334} \\
\hline & & & Administrators & 17,2 & 51,7 & 17,2 & & & & & \\
\hline & & & Supervisors & 9,1 & 45,5 & 43,6 & & & & & \\
\hline & \multirow{3}{*}{4} & \multirow{3}{*}{$\begin{array}{l}\text { Evaluation Results (appropriate } \\
\text { measurement and assessment, } \\
\text { announcement of results, recording the } \\
\text { grades to school's database...) }\end{array}$} & Teachers & 33,3 & 36,5 & & & 20,4 & & & \multirow{3}{*}{335} \\
\hline & & & Administrators & 20,8 & 54,2 & 16,7 & & & & & \\
\hline & & & Supervisors & 5,4 & 46,4 & 42,9 & & 5,4 & & & \\
\hline & \multirow{3}{*}{5} & & Teachers & 33,3 & 29,2 & & & 26,0 & & & \\
\hline & & $\begin{array}{l}\text { Homeworks (Planning, coherence with the } \\
\text { aim, follow up, evaluation...) }\end{array}$ & Administrators & 25,9 & 29,6 & 22,2 & & & & & 302 \\
\hline & & & Supervisors & 12,5 & 46,4 & 37,5 & & & & & \\
\hline & & Social Activities (Works of students clubs & Teachers & 34,2 & 41,8 & & & 8,9 & & & \\
\hline & 6 & and community services about scientific, & Administrators & 34,6 & 42,3 & 15,4 & & & & & 318 \\
\hline & & social, cultural, artistic and sports areas) & Supervisors & 5,5 & 49,1 & 43,6 & & & & & \\
\hline & & Guidance and Counselling Practices & Teachers & 31,0 & 42,0 & 8,2 & & & & & \\
\hline & 7 & (Educational, occupational, individual and & Administrators & 27,6 & 44,8 & 17,2 & & & & & 339 \\
\hline & & & Supervisors & 7,3 & 41,8 & 49,1 & & & & & \\
\hline & & Duties and Responsibilities (Teaching, & Teachers & 38,0 & 51,6 & 4,8 & & & & & \\
\hline & 8 & ceremonies, appearance, helping & Administrators & 33,3 & 55,6 & 7,4 & & & & & 330 \\
\hline & & administrators...) & Supervisors & 1,9 & 49,1 & 49,1 & & & & & \\
\hline & & & Teachers & 25,6 & 45,5 & 18,0 & & & & & \\
\hline & 9 & $\begin{array}{l}\text { meetings, seminars, graduate programs, } \\
\text { national and international projects and }\end{array}$ & Administrators & 16,7 & 45,8 & 29,2 & & & & & 286 \\
\hline & & scientific publications...) & Supervisors & 2,0 & 52,9 & 45,1 & & & & & \\
\hline & & & Teachers & 18,5 & 42,6 & & & 19,9 & & & \\
\hline & 10 & $\begin{array}{l}\text { Planning the lesson with effective time } \\
\text { management }\end{array}$ & Administrators & 15,4 & 38,5 & 19,2 & & 15,4 & & & 293 \\
\hline & & & Supervisors & & 52,9 & 43,1 & 2,0 & 2,0 & & & \\
\hline & & & Teachers & 20,0 & 48,1 & 12,7 & & & & & \\
\hline & 11 & Reflecting the aims and principles of national & Administrators & & 51,7 & 24,1 & & 10,3 & & & 341 \\
\hline ฮี & & & Supervisors & 1,9 & 51,9 & 46,2 & & & & & \\
\hline के & & & Teachers & 17,7 & 43,7 & & & 19,1 & & & \\
\hline on & 12 & Planning student centered lessons & Administrators & 14,3 & 39,3 & 25,0 & & 14,3 & & & 295 \\
\hline$\stackrel{000}{\sharp}$ & & & Supervisors & 1,9 & 46,2 & 50,0 & & 1,9 & & & \\
\hline$\Xi$ & & & Teachers & 21,5 & 37,6 & & & 19,5 & & & \\
\hline$\frac{\pi}{2}$ & 13 & Considering individual differences in lesson & Administrators & 19,2 & 42,3 & 15,4 & & & & & 285 \\
\hline & & & Supervisors & 3,7 & 48,1 & 44,4 & & & & & \\
\hline & & & Teachers & 22,4 & 42,0 & & & 18,3 & & & \\
\hline & 14 & $\begin{array}{l}\text { Defining the aims and objectives in lesson } \\
\text { plans }\end{array}$ & Administrators & 12,0 & 40,0 & 28,0 & & 12,0 & & & 297 \\
\hline & & & Supervisors & 3,8 & 42,7 & 45,3 & & 3,8 & & & \\
\hline & 15 & Specifying the purposeful activities in lesson & Teachers & 19,1 & 40,2 & & & 22,5 & & & 288 \\
\hline
\end{tabular}


Altun, B. \& Yengin Sarpkaya, P. (2020). The actors of teacher supervision. Journal of Human Sciences, 17(1), $284-303$. doi:10.14687/jhs.v17i1.5880

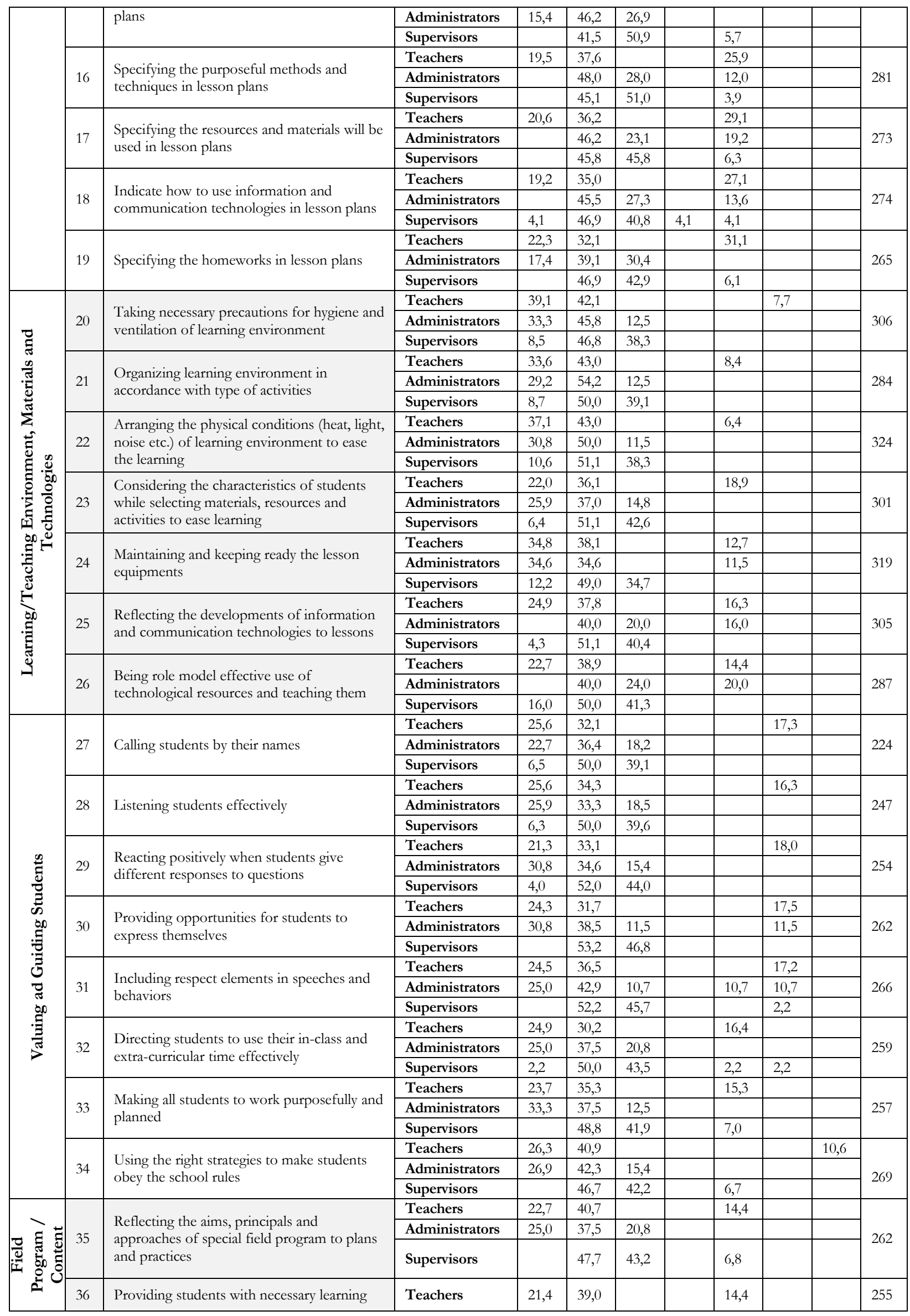


Altun, B. \& Yengin Sarpkaya, P. (2020). The actors of teacher supervision. Journal of Human Sciences, 17(1), 284-303. doi:10.14687/jhs.v17i1.5880

\begin{tabular}{|c|c|c|c|c|c|c|c|c|c|}
\hline & & \multirow[t]{2}{*}{ ways in special field } & Administrators & 25,0 & 41,7 & 25,0 & & & \\
\hline & & & Supervisors & & 47,7 & 43,2 & 6,8 & & \\
\hline & \multirow{3}{*}{37} & \multirow{3}{*}{$\begin{array}{l}\text { Transferring theories, principles and } \\
\text { concepts related to special field in a way that } \\
\text { students understand }\end{array}$} & Teachers & 20,4 & 36,1 & & 14,7 & & \multirow{3}{*}{257} \\
\hline & & & Administrators & 17,4 & 43,5 & 26,1 & & & \\
\hline & & & Supervisors & & 48,8 & 41,9 & 7,0 & & \\
\hline & \multirow{3}{*}{38} & \multirow{3}{*}{$\begin{array}{l}\text { Reflecting developments related to special } \\
\text { field to lessons (philosophy, theory, } \\
\text { approach...) }\end{array}$} & Teachers & 17,9 & 35,3 & & 15,8 & & \multirow{3}{*}{267} \\
\hline & & & Administrators & 16,7 & 37,5 & 29,2 & & & \\
\hline & & & Supervisors & 22,6 & 52,8 & 18,9 & & & \\
\hline & \multirow{3}{*}{39} & \multirow{3}{*}{$\begin{array}{l}\text { Motivating students to learn by attracting } \\
\text { their attention }\end{array}$} & Teachers & 14,6 & 35,4 & & 15,0 & & \multirow{3}{*}{281} \\
\hline & & & Administrators & & 24,0 & 20,0 & & 20,0 & \\
\hline & & & Supervisors & 24,0 & 58,0 & 16,0 & & & \\
\hline \multirow{24}{*}{ 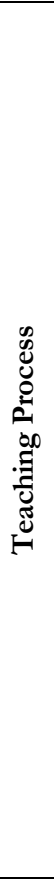 } & \multirow{3}{*}{40} & \multirow{3}{*}{$\begin{array}{l}\text { Examining the readiness of students in terms } \\
\text { of knowledge, skills and/or values to } \\
\text { understand the topic }\end{array}$} & Teachers & 16,9 & 33,3 & & 18,9 & & \multirow{3}{*}{276} \\
\hline & & & Administrators & 25,9 & 37,0 & 22,2 & & & \\
\hline & & & Supervisors & 25,0 & 60,4 & 12,5 & & & \\
\hline & \multirow{3}{*}{41} & \multirow{3}{*}{$\begin{array}{l}\text { Putting the content in gradual order } \\
\text { according to characteristics of topics }\end{array}$} & Teachers & 16,1 & 32,6 & & 24,9 & & \multirow{3}{*}{268} \\
\hline & & & Administrators & 20,0 & 28,0 & & 24,0 & & \\
\hline & & & Supervisors & 26,0 & 56,0 & 16,0 & & & \\
\hline & \multirow{3}{*}{42} & & Teachers & & 32,1 & & 24,9 & 15,0 & \\
\hline & & $\begin{array}{l}\text { Relating the topic of the lesson with the } \\
\text { previous topics }\end{array}$ & Administrators & & 37,0 & 25,9 & 14,8 & & 270 \\
\hline & & & Supervisors & 28,0 & 56,0 & 14,0 & & & \\
\hline & & & Teachers & & 32,1 & & 21,9 & 15,3 & \\
\hline & 43 & $\begin{array}{l}\text { Encouraging the learning efforts of students } \\
\text { at different levels }\end{array}$ & Administrators & 22,2 & 29,6 & 22,2 & & & 273 \\
\hline & & & Supervisors & 28,0 & 56,0 & 14,0 & & & \\
\hline & & & Teachers & 14,7 & 30,0 & & 22,6 & & \\
\hline & 44 & $\begin{array}{l}\text { Using the effective inquiry techniques } \\
\text { supporting higher order thinking skills }\end{array}$ & Administrators & 16,7 & 37,5 & 29,2 & & & 264 \\
\hline & & & Supervisors & 28,0 & 58,0 & 14,0 & & & \\
\hline & & & Teachers & & 26,7 & & 23,5 & 17,6 & \\
\hline & 45 & $\begin{array}{l}\text { Giving immediate feedback and correction to } \\
\text { students }\end{array}$ & Administrators & 14,8 & 33,3 & 14,8 & 14,8 & & 265 \\
\hline & & & Supervisors & 25,5 & 58,8 & 15,7 & & & \\
\hline & & & Teachers & & 31,3 & & 21,2 & 17,3 & \\
\hline & 46 & $\begin{array}{l}\text { Using voice tone, gestures and mimics } \\
\text { effectively in teaching process }\end{array}$ & Administrators & & 30,8 & & 15,4 & 19,2 & 254 \\
\hline & & & Supervisors & 26,5 & 61,2 & 19,2 & & & \\
\hline & & & Teachers & & 30,9 & & 19,3 & 17,7 & \\
\hline & 47 & $\begin{array}{l}\text { Creating opportunities for students to relate } \\
\text { what they have learned with their lives }\end{array}$ & Administrators & 20,8 & 33,3 & 20,8 & & & 254 \\
\hline & & & Supervisors & 26,5 & 59,2 & 12,2 & & & \\
\hline & & & Teachers & 17,9 & 33,8 & & 15,9 & & \\
\hline & 48 & $\begin{array}{l}\text { Acting in accordance with social and } \\
\text { professional ethical values in class activities }\end{array}$ & Administrators & 20,7 & 41,4 & 17,2 & & & 286 \\
\hline & & & Supervisors & 28,0 & 58,0 & 12,0 & & & \\
\hline & & & Teachers & 23,4 & 39,0 & & & 13,7 & \\
\hline 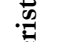 & 49 & Taking care of personal care & Administrators & 18,2 & 40,9 & 18,2 & & & 277 \\
\hline$\Phi$ & & & Supervisors & 28,0 & 58,0 & 12,0 & & & \\
\hline$\sqrt[\pi]{\tilde{U}}$ & & & Teachers & 16,2 & 37,1 & & 17,1 & & \\
\hline$\tilde{U}^{\mathfrak{J}}$ & 50 & $\begin{array}{l}\text { Using Turkish language grammatically and } \\
\text { understandably }\end{array}$ & Administrators & 11,5 & 42,3 & 19,2 & & 11,5 & 286 \\
\hline$\pi$ & & & Supervisors & 28,0 & 58,0 & 12,0 & & & \\
\hline$\underline{\underline{z}}$ & & & Teachers & 16,3 & 37,6 & & 14,4 & & \\
\hline : & 51 & Being a technology literate & Administrators & 16,0 & 44,0 & 24,0 & & & 279 \\
\hline$\Xi$ & & & Supervisors & 26,9 & 57,7 & 13,5 & & & \\
\hline & & & Teachers & 17,4 & 39,0 & & 15,0 & & \\
\hline & 52 & $\begin{array}{l}\text { Using time effectively in teaching-learning } \\
\text { process }\end{array}$ & Administrators & 13,8 & 44,8 & 20,7 & & & 296 \\
\hline & & & Supervisors & 24,1 & 53,7 & 20,4 & & & \\
\hline
\end{tabular}

Teachers often want the items in the document supervision dimension to be supervised by the school principal. After that, they prefer to the vice principal and head of the department. On the other side, the group who prefer the MoNE provincial supervisor the least is the teachers. Administrators, on the other hand, recommended the school principal, the MoNE provincial supervisor and the vice principal as the person to supervise the items of this dimension. It can be said that administrators are the group who prefer the head of the department the least. Supervisors often recommend the school principal and the MoNE provincial supervisor (themselves) as the person who will supervise the items of this dimension. When the percentages of opinions are examined, it is seen that almost all of the supervisors concentrate on these preferences. The head of the department and the vice principal are also preferred by supervisors with low rate. 
Teachers prefer school principal as a first, head of department as a second and vice principal as a third supervisory actor in the planning lesson dimension. MoNE provincial supervisor is proposed by teachers in the third place only for item 11. Administrators, on the other hand, genrally prefer the supervision of school principal and MoNE provincial supervisor for the items in this dimension. These preferences are followed by the vice principal. In addition, unlike the document supervision dimension, the administrators recommend head of department with a significant ratio. They think that the items in the dimension of planning the lesson can be supervised by the head of the department. Almost all of the supervisors recommend the school principal and the MoNE provincial supervisor as the supervisor of the items in the planning dimension. The head of the department and the vice principal categories are also preferred by the supervisors but the percentage of it is extremely low.

Teachers demand that the items in the dimension of learning / teaching environment materials and technologies be supervised mostly by the school principal and the vice principal. After that, they prefer the head of the department and student options. In addition, teachers prefer the supervision of the MoNE provincial supervisor at lowest level among others. Administrators, on the other hand, recommend the school principal and the vice principal to supervise the items of this dimension. These preferences are followed by the MoNE provincial supervisor and the head of the department. The supervisors suggested the ones, respectively the school principal, the MoNE provincial supervisor- that is, themselves- and the vice principal as the person who will control the materials in the dimension of learning / teaching environment tools and technologies;

Teachers often want the items of valuing and guiding students dimension to be supervised by the school principal. Afterwards, they prefer the vice principal and student options respectively. Teachers think students can supervise them in this dimension. In addition, the head of the department is the most preferred option for teachers after students. Administrators, on the other hand, recommend the school principal and the vice principal to supervise the items of this dimension. These preferences are followed by the MoNE provincial supervisor. In addition, the administrators suggest that students may supervise teachers in this dimension, unlike the other dimensions. These preferences are followed by the head of department. The majority of the supervisors recommend the school principal and the MoNE provincial supervisor as the person to supervise the items of this dimension. The head of the department and the vice principal are also proposed by the supervisors, albeit at a very low rate. In addition, this dimension is the only dimension where student option is expressed by the supervisors.

Teachers mostly want the items in the special field program / content knowledge dimension to be supervised by the school principal. These preferences are followed by the vice principle and the head of the department respectively. Administrators have often recommended the school principal, vice principal and the MoNE provincial supervisor as the person to supervise the items of this dimension. Almost all of the supervisors recommended the school principal and MoNE provincial supervisor. The head of the department and vice principal are also proposed by the supervisors, albeit at a very low rate.

Teachers think that the items in the teaching process dimension should be supervised by the school principal, head of the department and the student respectively. The category of vice principal is also suggested by considerable extent. On the other hand, administrators recommend the school principal. Then, the MoNE provincial supervisor and vice principle are respectively suggested. In this dimension, the supervisors mostly recommend the school principal and the vice principal. This reflects a different perspective than the general tendency of the supervisors in all dimensions of teacher supervision. The supervisors, who recommended themselves and the school principals in other dimensions, prefers school principals and vice principals in teaching process dimension.

Teachers believe that items of the dimension of individual characteristics should be supervised mostly by the school principal, vice principal and head of the department. Afterwards, they chose the student category. When the opinions of the administrators are subjected to 
examination, it is seen that the school principal, the MoNE provincial supervisor and the vice principal are suggested respectively. The supervisors recommend the school principal and the vice principal.

In summary, "teachers" is the group offering the most diverse opinions with the preferences of the school principal, vice principal, head of department, students and MoNE provincial supervisors for teacher supervision. According to the topic to be supervised, teachers think to be supervised by students. In addition, in the other category, the percentage of which is not given in the table, teachers are the only group who offer suggestions such as self-control, peer review, parents, and school counselors. The MoNE ministerial supervisor is not among their preferences. On the other hand, the administrators are more bound to the legislation and express their opinions around legal audit roles. Among the profession groups, administrators can be said to be the most directed group to the MoNE ministerial supervisor. They did not pay attention to students and other choices. Supervisors, on the other hand, are the group proposing the least variety included supervisory actors. In the supervision of teachers, they expressed little insight except for the school principal and the assistant principal.

\section{Results, Discussion and Suggestions}

As a result of the research, it has been found out that the school principal is preferred as the main supervisory actor. In general, it is the primary choice of participants in all dimensions of teacher supervision. Participants generally prefer the "document supervision" to be done by school principal, vice principal and head of department respectively. It is an intriguing result that the head of the department and the vice principle are among the primary choices, although they do not have a legal supervisory role. Since the document supervision includes the supervision of all the documents related to teaching, the proposal of the head of the department is an important finding. It can be inferred that participants rely upon the supervisions of the head of the department. Moreover, the MoNE ministerial supervisor is not generally preferred. In the dimension of "planning the lesson" the school principal, the vice principal, the head of the department and the MoNE provincial supervisor are mainly preferred, whereas in the dimension of "teaching / learning environment materials and technologies" the school principal and the vice principal are proposed as the main supervisor actor. Considering that the items of this dimension are related to the physical conditions of the school and classroom, cleaning of the environment and teaching materials, it is a meaningful finding to recommend the school principal and the vice principal as the people who know the school closely and can produce solutions in the shortest way.

In the dimension of "valuing and guiding students", the school principals', vice principals" and students' supervisions are suggested. The student category is suggested in the third place and it is a remarkable finding. The participants think that students can supervise teachers' status of valuing and guiding students. The proposed supervisory actors in the "special field program/content knowledge" dimension are the school principal, vice principal and MoNE provincial supervisor. The head of the department is also proposed at a rate close to the MoNE provincial supervisor. Although school principal and vice principal may not be the field peer of the teacher, it is interesting finding that they are suggested for the special field supervision. On the other hand, mainly the principal of the school, the head of the department and vice principle are recommended to supervise the teacher's "teaching process". The supervision of the teaching process somehow involves the supervision of classroom activities. Participants may have thought that supervision of teachers by school stakeholders would make them feel comfortable. In addition, the teacher's selfsupervision and parent supervision are also suggested at a very low rate for this dimension. Finally, teachers are expected to be supervised by the school principal and the vice principal about their individual characteristics. The head of the department, the student and the MoNE provincial supervisor are also proposed at a remarkable rate for this dimension. 
Choosing the school principal as the main supervisory actor can be related both to legal administrative and supervisory responsibility as well as being the person who knows the school and the teacher best. School principals are obliged to help teachers to find ways to make the school's program and teaching more effective due to their responsibilities (Henson, 2010, 70), so participants may want the school principal to supervise teachers based on this expectation. The findings of the research suggest that the school administrators' instructional supervisions have a positive effect on teachers' perceptions of school principals' reliability. Wahnee's (2010) research findings concluded that the instructional supervision variable was the strongest determinant of trust in the principal. Instructional supervision alone accounted for $98 \%$ of the in-school variables of trust in the principal. Consequently, the increase in the role of the principal in teacher supervision can increase the trust in the principal and thereby strengthen the corporate culture in school. On the other hand, it can be contemplated that the principals who will take part in teacher supervision should undergo some training in order to gain competence. According to the research findings of Minnear-Peplinski (2009), principals with a master's degree use more evaluation techniques both in number and variety. In addition, instructional supervision and leadership trainings provided to the administrators may be the source of their more productive approach to supervision. As a matter of fact, Grizzard (2007) reached the following conclusions: Between the principals who received instructional supervision training and applied clinical supervision technique and the one who did not receive training and apply the technique, a significant difference was found in terms of the number of teacher observations made to improve teaching. Moreover principals' instructional supervision skills affect teachers' job motivation (Yllmaz, 2019). So, all those variables may have effect on participants' preferences. On the other hand there are some research findings reflecting negative attitude of teachers about principals' supervisory roles. Koç's (2018) research findings reveal that teachers think that principals do not have enough time for supervision, they are not qualified enough, their personal relations and political preferences affect supervisions. All those concerns should be taken into consideration while structuring the supervisory roles of principals.

It is a significant finding that the participants suggest the principal as a supervisory actor, but when the work load and time problem of the principal are considered, there is a need to make some arrangements in the system. According to the research findings conducted by Kurt (2009) in order to get the opinions of the school administrators about the supervisory activities, school administrators do not adhere to a certain time schedule for supervisions. They improvise according to the proportion of teachers and workload. Most school administrators are dissatisfied with the existing supervision system in education. School principals are generally obliged to conduct supervisions in accordance with the directives received from the professional supervisors and the provincial directorate of national education. School administrators state that they experience difficulties when supervising teachers over a certain age or past retirement age. The school administrators believe that the supervised teachers are not satisfied because they observe stress, panic and excitement in the school personnel. When these findings are evaluated, it can be indicated that there is a need for problem solving and developing arrangements in school principal's supervisory roles.

It is an interesting finding of the current research that the MoNE Ministry supervisors are less preferred by participants. The MoNE provincial supervisors', who is officially responsible for teacher supervision, preference rate is also lower than the school principal. This may be due to the participants' problems about supervisions. For example, according to the findings of a study in which supervisors report their experiences on applied and administrative aspects of supervisions, real supervisory activities are not consistent with "successful clinical supervisory activities ". The supervisors stressed that they were not given sufficient time, resources and financial compensation to perform the ideal supervision. Many of the supervisors (66\%) did not take a course of clinical supervision during their training. $89 \%$ of the trainees of clinical supervision emphasized that they gained information through direct instruction. $70 \%$ of the supervisors stated that they did not have an internship experience (Rose, 2009). There are many studies like this pointing to the inadequacy 
Altun, B. \& Yengin Sarpkaya, P. (2020). The actors of teacher supervision. Journal of Human Sciences, 17(1), 284-303. doi:10.14687/jhs.v17i1.5880

of supervisors and problems related to their inadequacy (Yavuz, 1995; Macit, 2003; Kunduz, 2007; Çelik, 2010; Polat, 2010; Ilgaz, 2011; Karakuş, 2011; Köroğlu; 2011; Memduhoğlu and Rich, 2011). These inadequacies may prevent the supervisors from being preferred primarily.

It is interesting to note that the vice principal of the school is highly recommended by the participants, although there is no legal supervisory role of them. In some countries' supervisory systems, the vice principals have a supervisory duty. So, they may be the appropriate candidate to supervise teachers on certain issues. In the study of Begum (2008), the school principals were asked "Is the vice principal the most appropriate person to perform teacher supervision?" $56 \%$ of the participants said yes, $16,7 \%$ of them said no and $24,5 \%$ of them said vice principal is the most appropriate among possible options. Therefore, it can be stated that there is a need for legal regulations regarding the supervision duties of the vice school principals.

The head of the department is another education stakeholder who does not have a legal supervisory duty. The head of the department may be mostly preferred since the participants want the supervision of the teacher to be done by a field specialist. Today, peer review is an approach suggested by experts and it is claimed that it supports collaboration and development (Sullivan and Glanz, 2009, 154). In addition, in some research studies, one of the main problems that teachers put forward about supervision is that they cannot be supervised by field experts (Altun and Sarpkaya, 2014; Erim, 2004; Kaya, 2006). For this reason, the field expertise of the head of the department may be trusted and it may be preferable to supervise teachers.

It is also an important finding in terms of research that the student's supervision of the teacher, self-supervision and the supervision of the parents are in the suggested supervisory actors. Although it is not represented in detail in the Tables, the ratio of those actors are gathered under other option. The participants reflect the view that the teacher can be supervised by different people, albeit at a low rate. Since students, parents and teachers themselves are important supervisory actors of contemporary education systems, it is promising for the system readiness.

When the opinions of the participants are comparatively examined as teachers, administrators and supervisors, it is seen that different profession groups have different expectations for the person who will perform the supervisions. Teachers from the participants generally think that teacher supervision should be carried out by the school principal, vice principal and head of the department. Teachers among the all participants have the most diverse suggestions for supervisory actors. They are the only group that suggests students as supervisory actors at a remarkable rate. They also think that some characteristics of the teacher may be supervised by the MoNE provincial supervisor, MoNE ministry supervisor, school guidance service, special field peer, the teacher itself and parents, even with a low rate.

Administrators, in general, gave priority to school principals, vice principals and MoNE provincial supervisors as the actors of teacher supervision. It can be indicated that students and other options are not preferred by the administrators at a great extent. In some dimensions, the head of the department is also among the suggestions of the administrators.

The supervisors generally recommended the school principal and themselves to supervise the criteria used in teacher supervision. It is seen that the supervisors select only those who have the duty of supervision regulated by legislation. MoNE ministry supervisor, student, head of department and other options were not generally preferred by MoNE provincial inspectors.

The head of the department and also student categories were preferred mostly by the teachers among the participants. Administrators had little inclination to student category, and supervisors almost never. The MoNE provincial supervisor was most recommended by supervisors and least by teachers. The MoNE ministry supervisor was preferred with very low percentages throughout the study. The main reason for this may be the quantitative and qualitative inadequacies of the supervisors (Oktar, 2010). Teachers' negative opinion about inadequacy of the supervisors may have caused them to turn to the head of department and eliminate supervisors. 
While the teachers consider the supervisors insufficient, the supervisors think that teachers are reluctant in the guidance process (Erdem, 2010). There are serious differences in perception between teachers and supervisors (Oktar, 2010). According to the findings of Şahin (2005), the supervisors think that their qualification is at high and full level, and teachers think that it is at middle or low level, and in this study, there is a significant difference between the perceptions of supervisors and teachers about qualifications of supervisors. Similarly, according to the research findings of Köroğlu (2011), for the guidance of education supervisors, in the name of the professional development of their teachers, teachers and administrators indicated that it is at a "lower level" or "middle level" while education supervisors think that their guidance is at a "high level". These differences in perception may be one of the reasons why teachers find supervisors insufficient and do not prefer them first. It is an important finding that the officials appointed by the Ministry to supervisory positions are not preferred by the teachers. This may also be related to teachers' perception of the supervision as a control activity to find their weaknesses (Şener, 2011), but since teachers are not generally opposed to the supervision, it can be concluded that teachers may be disturbed during the supervisions performed by official supervisors. The other finding of Şener's (2011) study supports this view.

The research showed that the supervisors displayed an authoritarian and rebellious attitude during the implementation of supervisory process which is far from being guiding, and that the supervision did not adequately fulfill its main objectives, such as guidance and counseling. In addition, according to Balci's (2012) research findings, teachers think that supervisors use often a directive style, sometimes non-directive style and rarely cooperative style. MoNE made a legal regulation supporting these findings and excluded ministry supervisors from teacher supervision (MoNE, 2016a).

The reason for the supervisors to take on the supervisory duties to a certain extent may be that they consider themselves sufficient in this area. In the field, there is evidence that the efficacy perceptions of the supervisors are at a high level (Oktar, 2010; Şahin, 2005; Şener, 2011). Therefore, supervisors may think that the supervisions should be performed by themselves because their selfefficacy beliefs are at a high level. On the other hand, supervisors working under a heavy bureaucracy may have expressed their views in this direction because they are committed to law and authority. Based on the findings of this study, it could be concluded that the supervisors are not open to alternative supervisory choices.

There is research findings that teachers are not satisfied with the supervisions conducted by school principals. According to the research findings of Altun and Sarpkaya (2014), teachers think that the supervisions conducted by the school principals have no contribution other than to realizing which documents are missing. On the other hand, according to the research findings of Bayraktutan (2011), principals perceive their own supervisory skills at the "good" level and teachers perceive the supervisory skills of them at the "somewhat" level. Nevertheless, it is an interesting finding that teachers recommend the school principal for their supervision. This may be due to the fact that the teachers participating in the research have had qualified supervisory experiences with the school principals, or they may think that the school principal is the most effective person in the dynamics of the school. There are also research findings that most teachers are supervised by the school principal and vice-principal and supervisors are not actively involved (Tesfaw and Hofman, 2012). Therefore, the legal regulations regarding the supervisory role of the school principal and the vice school principal should be reviewed.

The suggestion of self-supervision activities by teachers represented under other option is also a meaningful finding. This type of supervision, which finds its application abroad, can be performed with the support of an expert in a healthy way. According to Özcan's (2011) research findings, there is self-supervision in schools in England. Schools are foreseen to supervise themselves once a year, and external evaluation is conducted every 5 years and self-supervision results are examined. In Turkey, the teachers' and the school's self-supervision is not concerned; schools are subjected to external supervision. Although parents and students are suggested as 
supervisory actors according to results of the current research, it is not in the legislation of MoNE. On the other hand, the situation is different in some countries. According to Berson's (2012) research findings, student feedback and parents' views are included in the final assessment of teacher supervision at the Roosevelt Foundation School, which is a successful school. Such supervisory approaches seem to be appropriate to the developmental needs of teachers.

In the light of the findings obtained from this study, where the opinions of supervisors, administrators and teachers about "Teacher Supervision" is tried to be determined, some suggestions can be brought to practitioners and researchers. The participants proposed the school principal as the teacher supervisor with the highest rate and consensus. Regulations can be made regarding the training of the school principal, workload and supervisory duties. As a supervisory actor, the vice principal and the head of the department are proposed at very high rates. On the other hand, these two stakeholders do not have any legal supervision duties. Regulations can be improved in this direction for a systematic cooperation. It is observed that the teachers were generally less oriented towards the supervisor option for the person who will conduct the supervisions. Trainings meetings and social events can be organized to strengthen supervisor teacher cooperation. Teachers have presented a variety of options as their supervisors, but in the existing system they can only be supervised by the school principal and MoNE provincial supervisors. The system can be reassessed to meet teacher needs in this direction. In addition, a study investigating the reasons why teachers did not choose supervisors could be designed. MoNE provincial supervisors evaluated the supervisory task as specific to themselves and school principals, and generally ignored other stakeholders. Research can be carried out in order to examine the reasons for their perception. A qualitative study can be conducted on the reasons for the differences of opinions of the supervisors, administrators and teachers regarding who should perform the teacher supervision. Qualitative research can be designed to reveal the reasons why participants do not generally prefer MoNE ministerial supervisors for teacher supervision.

\section{References}

Acheson, K. A. and Gall, M. D. (2003). Clinical supervision and teacher development-preservice and inservice applications. USA: John Wiley \& Sons, Inc.

Altun, B. and Yengin Sarpkaya, P. (2014, Nisan). Öğretmen ve okul müdürlerinin ders denetimine ilişkin görüşleri. I. Eurasian Research Congress, İstanbul Üniversitesi, İstanbul.

Aslanargun, E. and Göksoy, S. (2013). Öğretmen denetimini kim yapmalı? Uşak Üniversitesi Sosyal Bilimler Dergisi, Özel Sayn, 98-121.

Aydın, İ. (2013). Ögretimde denetim: Durum saptama, değerlendirme ve gelistirme. Ankara: Pegem Akademi Yayınc1lik.

Aziz, A. (2013). Sosyal bilimlerde arastirma yöntemleri ve teknikleri. Ankara: Nobel Yayıncıllk.

Balc1, A. (2007). Etkili okul ve okul gelistirme. Ankara: Pegem Akademi Yayıncilik.

Balc1, S. (2012). Öğretmenlerin egitim müfettişlerinin denetim stillerine ilişkin algzlar ile güven düreyleri arasindaki ilişki. (Unpublished Master Thesis). Niğde Üniversitesi, Eğitim Bilimleri Enstitüsü, Niğde.

Başar, H. (1998). Eğitim denetçisi. Ankara: Pegem Yayıncılık.

Bates, A. and Burbank, M.D. (2019) Agency in Teacher Supervision and Mentoring: Reinvigorating the Practice. New York, NY: Routledge.

Bayrak, M. and Yengin Sarpkaya, P. (2016, Kasım). Zümre öğretmenler kurulunun öğrenen takım haline dönüşmesi için meslektaş yardımlaşması bir uygulama örneği. EYFOR-7. Lefke Avrupa Üniversitesi, KKTC.

Bayraktutan, İ. (2011). İlkëgrretim okul müdürlerinin denetim rolleri (Sivas ili örneğgi). (Unpublished Master Thesis). Cumhuriyet Üniversitesi, Sosyal Bilimler Enstitüsü, Sivas.

Begum, F. (2008). Assistant principals and teacher supervision: roles, responsibilities, and regulations (Unpublished PhD Thesis). University of Houston, Calhoun. 
Altun, B. \& Yengin Sarpkaya, P. (2020). The actors of teacher supervision. Journal of Human Sciences, 17(1), 284-303. doi:10.14687/jhs.v17i1.5880

Berson, E., J. (2012). Teachers' perspectives of teacher supervision policies \& practices in charter schools in Pennsylvania (Unpublished Phd Thesis). Temple University, Philedelphia.

Brookover, W. B., Erickson, F. J. and McEvoy, A. W. (1995). Creating effective schools: an inserviceprogram for enhancing school learning climate and achievement. Viriginia: Learning Pulications.

Bursalığlu, Z. (2012). Okul yönetiminde yeni yapı ve davranıs. Ankara: Pegem Yayıncılık.

Büyüköztürk, Ş. (2005). Anket geliştime. Türk Eğitim Bilimleri Dergisi, 3(2), 297-315.

Çelik, İ. (2010). Ë̆itim müfettişlerinin inceleme ve sorusturma sürecinde yaptıklar hatalar (Unpublished Master Thesis). Ankara Üniversitesi, Eğitim Bilimleri Enstitüsü, Ankara.

Creswell, J. W. (2012). Educational research planning, conducting and evaluating quantitative and qualitative research. USA: Pearson Education, Inc.

Enns, F. (1965). Rating teacher effectiveness: The function of the principal. Journal of Educational Administration, 3(2), 81 - 95.

Erdem, A., and Sarpkaya, R. (2011). Postmodernizmin eğitim denetimine uygulanabilirliği. Mebmet Akif Ersoy Üniversitesi Sosyal Bilimler Enstitüsü Dergisi, (4), 73-85.

Erdem, H., B. (2010). Illköğretim müfettişlerinin görevlerini yerine getirirken karşılaşttğ sorunlar (Kahramanmaras ili örneği) (Unpublished Master Thesis). Yüzüncü Yıl Üniversitesi, Sosyal Bilimler Enstitüsü, Van.

Erdoğan, İ. (2012). Poritivist metodoloji ve ötesi. Ankara: Erk Yayıncılık.

Erim, A. Ç. (2004). Sosyal bilgiler öğretmenlerinin ilkö̈gretim müfettişlerinin teftislerine ilişlein görïsleri (Unpublished Master Thesis). Afyon Kocatepe Üniversitesi, Sosyal Bilimler Enstitüsü, Afyon.

Glickman, C. D., Gordon, S. P. and Ross-Gordon, J. M. (2009). The basic guide to supervision and instructional leadership. USA: Pearson Education, Inc.

Grizzard, T. (2007). The impact of instructional leadership on school climate: a model for principal and teacher improvement (Unpublished Phd Thesis). Tennessee State University, Nashville.

Henson, K., T. (2010). Supervision: A collaborative approach to instructional improvement. Waveland: Long Grove, IL.

Ilgaz, A. Ö. (2011). Öğretmen performansına denetimin ve yöneticilerin etkileri (Unpublished Master Thesis). Maltepe Üniversitesi, Sosyal Bilimler Enstitüsü, İstanbul.

İslamoğlu, A. H. and Alnıaçık, Ü. (2013). Sosyal bilimlerde araștirma yöntemleri. İstanbul: Beta Yayıncilik.

Kalule, L. and Bouchamma, Y. (2013). Supervisor's perception of instructional supervision. International Studies in Educational Administration, 41(1), 89-104.

Karakaya, İ. (2011). Bilimsel araştırma yöntemleri. A. Tantröğen (Eds.), In Bilimsel araştırma yöntemleri p. 55-84. Ankara: Anı Yayıncilik.

Karakuş, C. (2011). Ëğtim müfettişlerinin görev alanlarna ilişkin öz-yeterlilik algısı (İstanbul ili örneği) (Unpublished Master Thesis). Yeditepe Üniversitesi, Sosyal Bilimler Enstitüsü, İstanbul.

Kaya, E. (2006). An investigation into the supervisory process from the standpoint of the supervised elt teachers with a focus on their perceptions, ideas, feelings, and experiences (Unpublished Master Thesis). Karadeniz Teknik Üniversitesi, Sosyal Bilimler Enstitüsü, Trabzon.

Knoll, M. K. (1987). Supervision for better instruction. New Jersey: Prentice Hall, Inc.

Koç, İ. (2018). Okul müdürlerinin ders denetim görevlerinin öğretmen görüsllerine göre değerlendirilmesi. (Unpublished Master Thesis). Tokat Gaziosmanpaşa Üniversitesi, Eğitim Bilimleri Enstitüsü, Tokat.

Köroğlu, H. (2011). Eğitim müfettislslerinin rehberlik rollerine yönelike ögrretmen, yönetici ve eğitim müfettisi görüsleri (Samsun ili örneği) (Unpublished Master Thesis). Ondokuz May1s Üniversitesi / Eğitim Bilimleri Enstitüsü, Samsun.

Kunduz, E. (2007). İlköğretim müfettişlerinin çağdas eğitim denetimi ilkelerine ve kliniksel denetime yönelik davranıslarna ilişkin ögretmen algzları. (Unpublished Master Thesis). Yıldız Teknik Üniversitesi, Sosyal Bilimler Enstitüsü, İstanbul. 
Altun, B. \& Yengin Sarpkaya, P. (2020). The actors of teacher supervision. Journal of Human Sciences, 17(1), 284-303. doi:10.14687/jhs.v17i1.5880

Kurt, S. (2009). Illkögretim kurumlarndaki yöneticilerin denetleme faaliyetlerine ilişkin yönetici görüslerinin değerlendirilmesi (Unpublished Master Project). Trakya Üniversitesi, Sosyal Bilimler Enstitüsü, Edirne.

Lodico, M. G., Spaulding, D. T. and Voegtle, K. H. (2006). Methods in educational research from theory to practice. San Francisco: Jossey-Bass.

Macit, M. (2003). Illkögretim denetmenlerinin denetimler surasinda denetim ilkelerine uyma düzeyleri (Unpublished Master Thesis). Dokuz Eylül Üniversitesi, Eğitim Bilimleri Enstitüsü, İzmir.

Marzano, R. J., Frontier, T. and Livingston, D. (2011). Effective supervision - supporting the art and science of teaching. Virginia: ASCD Member Book.

Memduhoğlu, H. B. and Zengin, M. (2011). Çağdaş eğitim denetimi modeli olarak öğretimsel denetimin türk eğitim sistemine uygulanabilirliği. Kurmsal Eğitimbilim Dergisi, 5(1), 131-142.

Minnear-Peplinski, R. M. (2009). Principals' and teachers' perceptions of teacher supervision (Unpublished $\mathrm{PhD}$ Thesis). University of Nevada, Las Vegas.

MoNE (2003). İlkögrretim Kurumlar Yönetmelĭgi. Retrieved from http://eokul.meb.gov.tr/Dokumanlar/ ILKOGETIM_YONETMELIGI.pdf. 10.10.2013.

MoNE (2011). Ögretmen Denetim Rehberi. Retrieved from http://rdb.meb.gov.tr/yayinlar/\%C3 \%96\%C4\%9Fretmen_Denetim_Rehberi.pdf. 15.05.2014.

MoNE (2013). Milli Ĕ̈itim Bakanluğ Ortä̈gretim Kurumlar Yönetmeliği. Retrieved from http://www .resmigazete.gov.tr/eskiler/2013/09/20130907-4.htm. 15.05.2014.

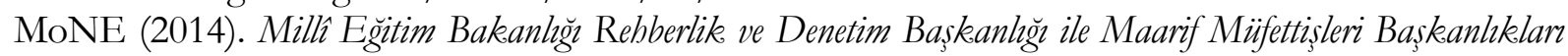
Yönetmelï̈i. Retrieved from http://www.resmigazete.gov.tr/eskiler /2014/05/2014052418.htm. 15.05.2014.

MoNE (2016a). Lise ve Dengi Okullar Denetim Rehberi. Retrieved from http://tkb.meb.gov.tr/meb iys dosyalar/2016 11/14010033 lise ve dengi okullar rehbe rlik ve denetim rehberi 2016.doc. 22.08.2019.

MoNE (2016b). MEB Ortaöğretim Kurumlar1 Yönetmeliği. Retrieved from https://ogm.meb.gov.tr/meb iys dosyalar/2016 11/01062228 meb ortaogretim kuruml ari yonetmeligi $28 \quad 10$ 201629871.pdf 22.08.2019.

Muijs, D. (2004). Doing quantitative research in education with spss. London: Sage Publications.

Neuman, W. L. (2007). Basics of social research qualitative and quantitative approaches. USA: Pearson Education, Inc.

Oktar, A., N. (2010). Eğitim denetim sisteminin yasal dayanaklara göre değerlendirilmesi (Unpublished Master Thesis). Dokuz Eylül Üniversitesi, Eğitim Bilimleri Enstitüsü, İzmir.

Özcan, B. E. (2011). Ingiltere ve Türk eğitim sisteminde teftis ve değerlendirmesinin karşzlasstrmal olarak incelenmesi (Unpublished Master Thesis). Yeditepe Üniversitesi, Sosyal Bilimler Enstitüsü, İstanbul.

Polat, G. (2010). Eğitim yönetimi ve denetimi anabilim dalnnda yapılmış lisansüstü tez, calısmalarmmn incelenmesi. (Unpublished Master Thesis). Maltepe Üniversitesi, Sosyal Bilimler Enstitüsü, İstanbul.

Rossi, P. H., Wright, J. D., and Anderson, A. B. (2013). Sample surveys: History, Current practice, and future prospects. (Ed. P. H. Rossi, J. D. Wright ve A. B. Anderson). In Handbook of survey research p. 1-20. New York: Academic Press.

Şahin, T. (2005). Illkögrretim dürgyinde ders denetimiyle ilgili yeterlilikler hakekinda denetmen ve ögretmen görüsler (Unpublished Master Thesis). Abant İzzet Baysal Üniversitesi, Sosyal Bilimler Enstitüsü, Bolu.

Scott, D. and Morrison, M. (2007). Key ideas in educational research. London: Continuum.

Şener, M. (2011). Eğitim ve bakanllk müfettişlerinin teftis uygulamalarna iliskin öğretmen görüslerinin değerlendirilmesi (Unpublished Master Thesis). Kurkkale Üniversitesi, Sosyal Bilimler Enstitüsü, Kırıkkale.

Sergiovanni, T. J. and Starratt, R. J. (1979). Supervision human perspectives.USA: McGraw-Hill, Inc.

Sindhvad, S. P. (2009). School principals as instructional leaders: an investigation of school leadership capacity in the Philippines (Unpublished Master Thesis). University of Minnesota. 
Altun, B. \& Yengin Sarpkaya, P. (2020). The actors of teacher supervision. Journal of Human Sciences, 17(1), 284-303. doi:10.14687/jhs.v17i1.5880

Sullivan, S. and Glanz, J. (2000). Alternative approaches to supervision: cases from the field. Journal of Curriculum and Supervision, 15(3), 212-235.

Sullivan, S. and Glanz, J. (2009). Supervision that improves teaching and learning. California: Corwin A SAGE Company.

Taymaz, H. (2011). Eğitim sisteminde teftis. Ankara: Pegem Akademi Yay1nc1lk.

Temiz, S. (2018). Okul müdürlerinin denetim rollerine ilişkin ögretmen algzlarmin incelenmesi (Şanluurfa ili örneği). (Unpublished Master Thesis). Gaziantep Üniversitesi, Eğitim Bilimleri Enstitüsü, Gaziantep.

Tesfaw, T. A. and Hofman, R. H. (2012). Instructional supervision and its relationship with professional development: perception of private and government secondary school teachers in Addis Ababa (Unpublished PhD Thesis). University of Groningen, Holland.

Ültanır, G. (2003). Ë̆itimde planlama ve değerlendirmede kuram ve teknikler. Ankara: Nobel Yayıncilık.

Wahnee, R. L. (2010). The effect of instructional supervision on principal trust (Unpublished PhD Thesis). University of Oklahoma, Norman, Oklahoma.

Wiles, J. and Bondi, J. (2000). Supervision a guide to practice. New Jersey: Prentice Hall.

Wolfrom, D. H. (2009). Promoting professional growth by meeting teacher needs: the walk-through as an approach to supervision (Unpublished $\mathrm{PhD}$ Thesis). University of Southern Maine, Portland.

Yavuz, Y. (1995). Ögretmenlerin denetim etkinliklerini klinik denetim ilkeleri açısından değerlendirmeleri (İzmir örneği). (Unpublished Master Thesis). Dokuz Eylül Üniversitesi, Sosyal Bilimler Enstitüsü, İzmir.

Yengin Sarpkaya, P. (2013). Yönetim kuramları ve eğitime yansıması. R. Sarpkaya (Ed.), In Türk eğitim sistemi ve okul yönetimi p. 135-166. Ankara: An1 Yayıncilik.

Y1lmaz, E. (2019). Öğretmen algzlarna göre okul müdürünün ögretimsel denetim davranışlarnmn ögretmen motivasyonuna etkisi (Unpublished Master Thesis). Düzce Üniversitesi, Sosyal Bilimler Enstitüsü, Düzce.

Yslmaz, K. (2009). Okul müdürlerinin denetim görevi. Dumlupinar Üniversitesi Ë̆itim Fakültesi Dergisi, 10(1), 19-35. 